\title{
68- Unravelling the beliefs and practices of EFL teachers related to corrective feedback in Turkey
}

\section{Zehra ÇOBAN ${ }^{1}$ \\ Banu İNAN KARAGÜL ${ }^{2}$}

\begin{abstract}
APA: Çoban, Z.; İnan Karagül, B. (2021). Unravelling the beliefs and practices of EFL teachers related to corrective feedback in Turkey. RumeliDE Dil ve Edebiyat Araştırmaları Dergisi, (25), 1103-1119. DOI: 10.29000/rumelide.1037126.
\end{abstract}

\begin{abstract}
Recent studies in Second Language Acquisition (SLA) have shown that there is an apparent relationship between teachers' beliefs and their classroom practices of oral corrective feedback in second language teaching. Even though many experimental and classroom studies show that it is beneficial for second language acquisition, relatively little research has explored the relationship between beliefs and practices of teachers in terms of oral corrective feedback. This descriptive study aims to examine the relationship between teachers' stated beliefs and their practices about oral corrective feedback in classrooms in a Turkish EFL setting. The data were collected through classroom observations of ten EFL teachers working at a preparatory language school of a privately funded university in Turkey, semi-structured interviews and scenario-based error correction simulation. The results showed that most of the teachers have an awareness of oral corrective feedback and believe that it is useful for students when provided appropriately to avoid touching learners' affective states negatively. Recasts were observed as the most frequently employed feedback type because of its implicit nature, even though most of the instructors reported elicitation as the most effective corrective feedback strategy. In this respect, the results revealed inconsistencies between teachers' stated beliefs and their actual practices about oral corrective feedback; that is, the types of errors corrected in the classroom also showed deviation from the teachers' stated beliefs.
\end{abstract}

Keywords:Corrective feedback, EFL, learner errors, teacher beliefs

\section{Türkiye'deki İngilizce öğretmenlerinin düzeltici geri bildirimle ilgili inanç ve uygulamalarının belirlenmesi}

\author{
$\ddot{\mathbf{O z}}$
}

İkinci Dil Edinimi (İDE) ile ilgili yapılan son çalışmalar, öğretmenlerin inançları ile ikinci dil öğretiminde sözlü düzeltici geribildirim sınıf uygulamaları arasında belirgin bir ilişki olduğunu göstermiştir. Her ne kadar birçok deneysel ve sınıf çalışması düzeltici geri bildirimin ikinci dil edinimi için faydalarını gösterse de, buna oranla çok az araştırma öğretmenlerin inançları ve uygulamaları arasındaki sözlü düzeltici geri bildirim açısından ilişkisini incelemiştir. Bu betimsel çalışma, anadilin Türkçe olduğu bir ortamda Yabancı dil olarak İngilizce öğretimi sınıflarında öğretmenlerin sözlü düzeltici geri bildirimle ilgili ifade ettikleri inançları ve sınıf içi uygulamaları arasındaki ilişkiyi incelemeyi amaçlamaktadır. Veriler, Türkiye'de bir vakıf üniversitesinde çalışan on İngilizce

Öğr. Gör., Gebze Teknik Üniversitesi, Yabancı Diller Bölümü (Kocaeli, Türkiye), zehra.cobann@gmail.com, ORCID ID: oooo-0002-6055-9389 [Araştırma makalesi, Makale kayıt tarihi: 26.10.2021-kabul tarihi: 20.12.2021; DOI: 10.29000/rumelide.1037126]

2 Doç. Dr., Kocaeli Üniversitesi, Eğitim Fakültesi, Yabancı Diller Eğitimi (Kocaeli, Türkiye), banu_inan@yahoo.com, ORCID ID: 0000-0001-8672-1383 
öğretmeninin ders gözlemleri, yarı yapılandırılmış görüşmeler ve senaryo tabanlı hata düzeltme simülasyonu yoluyla toplanmıştır. Sonuçlar, öğretmenlerin çoğunun sözlü düzeltici geri bildirim farkındalığına sahip olduğunu ve öğrencilerin duygusal durumlarını olumsuz etkilemekten kaçınmak için uygun bir şekilde verildiği zaman öğrenciler için yararlı olduğuna inandıklarını göstermiştir. Eğitmenlerin çoğu, en etkili düzeltici geri bildirim stratejisi olarak ortaya çıkarmayı (Elicitation) belirtmiş olsa da, örtük doğası nedeniyle en sık kullanılan geri bildirim türü olarak yeniden düzenleme (Recast) gözlemlenmiştir. Bu bağlamda, sonuçlar öğretmenlerin sözlü düzeltici dönütle ilgili ifade ettikleri inançları ile gerçek uygulamaları arasında tutarsızlıklar olduğunu ortaya çıkarmıştır. Sınıfta düzeltilen hata türleri de öğretmenlerin belirtilen inançlarından sapma göstermiştir.

Anahtar kelimeler: Düzeltici dönüt, İngilizce, öğrenci hataları, öğretmen inançları

\section{Introduction}

In the last 25 years, there has been a substantial increase in the number of studies focusing on language teacher cognition. Borg (2006) defines teacher cognition as a complex construct consisting of knowledge, beliefs and thoughts held by language teachers based on their actions and instructional decisions. The relationship between teachers' beliefs and actual classroom practices has been investigated in some studies examining different aspects of a second/foreign language; namely, writing (Gaitas\& Martins, 2014; Hsiang et al., 2020), reading (Kuzborska, 2011), grammar (Uysal\&Bardakçı, 2014), pronunciation (Bai \& Yuan, 2018), and vocabulary (Mardali et al., 2019). The findings reported in these studies and many others has led to both congruence and incongruence between what teachers believe and what they actually do in the classroom and the reasons underlying these similarities and differences. Since teacher beliefs are considered to shape their thoughts (Baştürkmen et al., 2004) and their instructional decisions (Richards, 1998), their investigation to get a better understanding of what is happening in the classroom bears importance. However, as suggested by Kurbanyiova\&Ferlok (2015), what is illustrated in the mainstream language teacher cognition research generally is under the influence of the cognitivist paradigm, it therefore gives a limited 'epistemological landscape' for understanding the concept of teacher cognition (p.436). What is proposed related to language teacher cognition research is to analyze it within its own ecological setting. In this sense, discourse analytic, narrative and ethnographic approaches are mostly recommended to address the link between beliefs and actual practices (Kurbaniova\&Ferlok, 2015). Within this context, analysis of classroom discourse and the reflections of language teachers' beliefs on their interactional behavior require a better understanding. With this idea in mind, EFL teachers' oral corrective feedback practices, an important aspect of teachers' classroom interactional behavior, have been investigated extensively in a variety of different contexts and those studies (Kamiya, 2016; Ölmezer-Öztürk, 2019; Roothoft, 2014) have led to different results.

\section{Corrective Feedback}

Corrective feedback (CF henceforth) refers to utterances which indicate that the learner's output is erroneous in some way (Nassaji\&Kartchava, 2017). It is acknowledged that CF is an important part of L2 teaching practice, whether learner errors should be corrected, ways of correcting them, timing of error correction, who should correct them and which types should be corrected have led to controversies (Hendrikson, 1978). In the observational studies, corrective feedback moves were classified into 
different types. Lyster\&Ranta (1997), which is among the most frequently cited studies, initially classified CF moves into six categories. These categories and the examples are given in Table 1 below:

Table 1: Corrective feedback types

Corrective Feedback Types $\quad$ Definitions (Lyster\&Ranta, 1997; $\quad$ Examples (from our own data)

Explicit Correction

Recasts

Clarification request

Metalinguistic feedback

Elicitation

Repetition
The teacher explicitly provides the correct form and clearly says that what the student said is incorrect (Lyster\&Ranta, 1997)

The teacher reformulates the learner's utterance either partially or fully without the error.

(Lyster\&Ranta, 1997)

They indicate to students either that their utterance has been misunderstood by the teacher or that the utterance is ill-formed in some way and that a repetition or a reformulation is required (Spada\&Fröhlich, 1995, p.25).

They include teacher's comments, information or questions related to the correctness of the students' utterance, but they do not explicitly provide the correct form.

The teacher directly elicits the correct form from the student using at least three methods, such as eliciting completion of their own utterance, using questions to elicit correct forms or occasionally asking students to reformulate their utterance (Lyster\&Ranta, 1997, p. 48).

The teacher repeats, in isolation, students' erroneous utterance. "In most cases, teachers adjust their intonation so as to highlight the error (Lyster\&Ranta, 1997, p. 48)."
T: Who is she talking to?

S: policeman.

T: Don't say policeman. It is Police officer, police officer.

S: They didn't success at school.

T: They didn't succeed at school.

T: You can talk about what you remember, what you have written, before we move to the next part. Anything?

S: We will be expert if we do something for twenty-four hour a week.

T: Sorry, what did you say?

S: twenty-four hours a week.

T: Is it well-paid or badly-paid?

S: middle

$\mathrm{T}$ : You need to use a preposition before it.

$\mathrm{S}$ : in the middle. It depends on where you work and it depends on your experience.

S: Puzzle is developing our brain.

T: Puzzles ... our brain!

S: Puzzles develop our brain.

T: Yes, they develop our brain.

S: When you go to Starbucks, it is good thing because you see lots of culture people.

T: culture people?

S: from different cultures, different types of people. 
However, afterwards, they created two broader categories; namely, prompts and reformulations (Ranta\&Lyster, 2007). On the other hand, in a more recent publication, Ellis (2012) put forward a different categorization of CF strategies as shown in Table 2 below:

Table 2:Ellis's (2012) Corrective Feedback Types

\begin{tabular}{lll}
\hline & Implicit & Explicit \\
\hline Input providing & Recasts & Explicit correction \\
\hline Output prompting & Repetitions & Metalinguistic comments \\
\hline & Clarification requests & Elicitation \\
\hline
\end{tabular}

In this classification, 'input-providing' CF strategies 'provide learners with the correct target form' and 'output-prompting' CF strategies, on the other hand, 'push learners to self-correct their own errors' (p.265). He also stated that these strategies are not always used in isolation; in fact, in most cases, what teachers do is using multiple strategies in order to correct an error. Despite these recent modifications, the most frequently cited and the most comprehensive categorization by Lyster\&Ranta (1997) was taken as the reference point in this study.

The important connection between teacher beliefs and practices has already been revealed (Borg, 2011). When it comes to teachers' beliefs and practices of oral corrective feedback, the studies generally led to mixed results. While some of the studies found consistencies (Jensen, 2001; Kamiya, 2016), some others revealed differences between teacher beliefs and practices (Baştürkmen et al., 2004; Roothooft, 2014). For instance, Kamiya (2016), investigated the beliefs and practices of four ESL teachers at an intensive language program and found that the participant teachers' beliefs and practices are consistent. These teachers stated that their preferred form of corrective feedback was recast and in their actual practice, they mainly used this strategy to correct student errors. On the other hand, Roothooft (2014) included ten Spanish adult EFL teachers in her study and she observed differences between the types of corrective feedback they found helpful and the corrective feedback they used in the classroom was different from each other.

When it comes to the studies in the context of Turkey, there are very few studies focusing on the relationship between EFL teachers' beliefs and practices of OCF (Ölmezer-Öztürk, 2019; Özmen \& Aydın, 2015). Ölmezer-Öztürk (2019) investigated the relationship between the EFL teachers working in the preparatory program of a university and found out individual variation among the participant teachers despite the fact that they were using the same material. Furthermore, her study revealed consistency between their beliefs and practices in terms of the amount of OCF they provide, but it is not the case for the timing and the type of OCF. On the other hand, Özmen \& Aydın (2015) included preservice EFL teachers as their study participants and found out differences between their error correction practices depending upon language proficiency, language components and task type despite the similarities between their conceptualizations of teaching. The necessity of gathering more data about teachers' beliefs and practices was indicated if we intend to see the impact of L2 research on actual practice and the training of teachers (Roothooft, 2014). In this sense, it is believed that this study will contribute to the related literature, which is sparse in the Turkish EFL context.

\section{Method}

\section{The context of the study}


This study was conducted in the English preparatory program of a foundation university in the spring semester of 2018-2019 academic year in Turkey. It is a classroom-based study, which, as Spada and Lightbown (2009) stated, makes a better understanding of classroom interaction possible in a context where the teacher is the sole speaker interacting with the students in a classroom environment. In this study context, the students who enroll in an undergraduate program, in which English is partly or wholly the medium of instruction, are first supposed to take Foreign Language Proficiency Exam (Exemption Exam) after which they either attend the preparatory program or attend the departmental courses in their faculties depending on their exam performance. The aim of the program is to equip students with a basic level of English proficiency and to assist students to develop their reading, writing, listening and speaking skills, and grammar. Therefore, students have a strong reason to improve their English language skills because their future academic success will depend on their efforts during this preparatory year.

\section{Research questions}

1. What are the English language teachers' beliefs and practicesabout oral corrective feedback?

2. To what extent there is congruence or incongruence between their beliefs and practices?

\section{Participants}

The participants of this study include ten Turkish EFL teachers teaching in the preparatory program of a privately funded university in Turkey. During the preparatory year, students improve their English proficiency as the medium of instruction is either partially or fully English depending on the department. Two of them were males and eight of them were females. The participants have teaching experience ranging between 5 and 20 years. All of them hold an English language-related bachelor's degree. Six of the teachers have more than ten years of experience, and four have 5-10 years of experience. The teachers were selected on the basis of their schedule and availability. The ten teachers were given Pseudonyms T1 to T10 and the details related to the participants are given in Table3 below. 
1108 / RumeliDE Journal of Language and Literature Studies 2021.25 (December)

Unravelling the beliefs and practices of EFL teachers related to corrective feedback in Turkey / Z. Çoban; B. İnan Karagül (pp. 1103-1119)

Table 3:Demographic information about the participants

\begin{tabular}{llll}
\hline Teacher (Pseudonyms) & Experience & Degree & Field of study \\
\hline T1 & Over 10 years & BA & ELL \\
\hline T2 & Over 10 years & MA & ELT \\
\hline T3 & 5-10 years & BA & EL \\
\hline T4 & 5 -10 years & BA & ELT \\
\hline T5 & 5 -10 years & BA & ELL \\
\hline T6 & Over 10 years & PhD & ELL \\
\hline T7 & Over 10 years & MA & ELT \\
\hline T8 & 5-10 years & MA & ACL \\
\hline T9 & Over 10 years & MA & ELT \\
\hline T10 & BA years &
\end{tabular}

As shown in Table 3 above, the participants include EFL teachers having experience either between 5 to 10 years (less experienced) or over 10 years (experienced). 4 of the participants belong to the 'less experienced' teacher category and 6 of them belong to the 'experienced' teacher category.

\section{Data collection}

Initially, the researchers got all the students' and the participant teachers' consent to collect data and use it for this study. Afterwards, ethical approval was obtained from one of the state universities in Marmara Region, Turkey (Date: 9/7/2020, number: 44811/13). As the researchers aimed to investigate the relationship between teachers' stated beliefs and practices about oral corrective feedback, different data collection techniques; namely, non-participant observation, class audio-recordings, semistructured interviews and scenario-based error correction with the participant instructors were utilized. In order to identify the teachers' beliefs thoroughly, the framing questions proposed by Hendrickson (1978) have been borrowed as interview questions because his study is one of the first comprehensive studies on error correction. The observations were planned depending on the availability of the teachers and the researcher. All the classes in which observations were carried out were chosen in line with the aims of the study. The main focus of the observed classes was two language skills; namely, listening and speaking, which generally include interaction between students and teachers. Each class contained many different activities, such as classroom discussions, dialogues, etc. So that different types of oral corrective feedback occurred and utilizied for the analysis. The oral interaction was formed in accordance with the course book followed and on semi-structured speaking activities. 


\section{Procedure}

The class observations constitute the first stage of the process. Ten Turkish EFL teachers participated in the study. We observed each teacher 2 class hours on two occasions, a total of 180 minutes each. The total duration of the observations was 1800 minutes, which comprises 30 hours. The number of students in the classes observed was between 6 and 21. Classroom interaction in the observed classes was performed by following the topic and themes in the coursebook used by the course instructors. During the observations, the researcher was present in the classroom as an observer and audio-recorded the entire process. The researcher took field related notes, as the lessons were being audio-recorded. The participant teachers were not informed about the focus of the study in view that it might affect teachers' treatment of errors. Instead, they were just told that the interaction between the teacher and the students and peers was the focus of the researcher.

\section{Data analysis}

After observations were completed, the researchers transcribed the recordings verbatim in order to identify oral corrective feedback (OCF) types, characteristics of OCF provided and learner error types. Content analysis (Neuendorf, 2002) was employed in order to analyze the recordings and to identify teachers' oral feedback performances. This methodology is similar to the one adopted in previous studies of OCF, such as Lyster and Ranta (1997), Panova and Lyster (2002) and Lyster (2004). The researchers calculated the number of spoken errors and the percentage of errors corrected by the teachers. Errors were categorized into three groups; namely, grammar, vocabulary, and pronunciation. Allwright and Bailey's (1991) definition of errors, "the utterances differ from native-speaker norms" (p.86) and "teacher signal as needing improvement," (p.86) was used to identify student errors and teacher feedback. We coded CF episodes in accordance with Lyster and Ranta's (1997) taxonomy of OCF types and analyzed them in the light of Hendrickson (1978). Interrater reliability analysis was conducted for OCF patterns in the classroom conversations. An external rater was invited to analyze a randomly selected proportion of the whole data (50\%). She was informed about the study's objectives and the taxonomy of the OCF types by Lyster and Ranta (1997). After that, interrater reliability was calculated and it was found to be $99 \%$ for error types and $98 \%$ for OCF types.

After the observation data was collected and analyzed, a semi-structured interview was scheduled with each participating teacher. Prior to the interviews, the teachers were provided with an information sheet including a general outline of OCF types set by Lyster and Ranta (1997). Ten EFL instructors took part in the interview and the questions in the interview focused on their beliefs about OCF in line with Hendrickson's (1978) five questions and six particular types of feedback introduced by Lyster and Ranta (1997). The interviews were recorded and analyzed qualitatively to identify both the common themes and the differences between the teachers' stated beliefs and their actual classroom practices. In order to support the findings of the other data collection tools, scenario-based error correction was also conducted. The participant teachers were given a paper including student generated errors and their correction scenarios designed based on Lyster and Ranta's (1997) taxonomy. Afterwards, the teachers were asked whether they would correct the errors or not, if they did, which scenario they would choose (see Appendix). The diversity of the methods of data collection in this study is believed to ensure the validity and reliability of the data gathered as research generates higher quality when more than one method is utilized (Patton, 2002). 


\section{Results}

The first research question in this study sought to find out the participant teachers' beliefs and practices about OCF. Some prepared scenarios were given to the participants and they were asked to evaluate the scenarios. First of all, the participant teachers' beliefs and practices related to whether learner errors should be corrected or not were investigated. When we analyze the answers given by the teachers to the questions in the interview, almost all teachers have the same opinion that corrective feedback is useful and it is effective if delivered in the right way. The participating teachers expressed their views on the level of effectiveness of oral corrective feedback, highlighting a few key points. For instance, two of the participant teachers suggested that "it should be given thoughtfully and appropriately not to demotivate students. Unless corrected by the teacher, some errors would recur, and students would feel that they have made no errors while speaking. However, if the errors are some minor ones, they could be ignored in order not to de-motivate students." Another teacher stated that because repeated errors may lead to learning very fast and easily, correction of them is an inevitable attitude for teachers to avoid instilling them in learners.

With regard to teachers' classroom practices, $61 \%$ of erroneous statements were corrected and $39 \%$ were not, which may be due to a widespread belief by many of the participants that overcorrection can cause negative emotional reactions and low self-esteem and inhibition. However, in scenario-based practices, teachers preferred to correct $84 \%$ of the incorrect statements in the cued response scenarios and left 16 percent untreated. All teachers preferred to correct more than half of the mistakes. Secondly, the participant teachers' beliefs and practices about the ways of correcting learner errors were investigated. The participant teachers' comments on the most appropriate type of corrective feedback vary. Figure 1 below shows the percentages of the participant teachers' beliefs about the type of OCF that should be used to correct student errors:

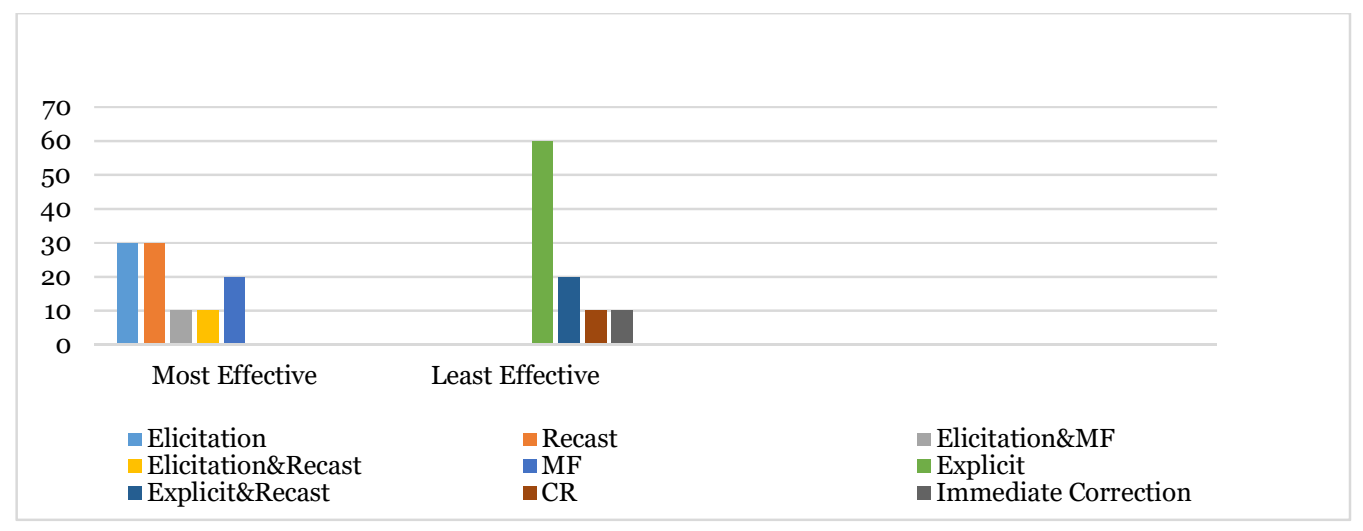

Figure 1: Teachers' Beliefs of the most and the Least Effective Corrective Feedback Types

As shown in Figure 1, in the answers given by the teachers to the question about the techniques they find the least or most effective, it can be seen that $30 \%$ of the teachers believe that eliciting itself is the most effective type of corrective feedback. $10 \%$ of teachers agreed that both elicitation and metalinguistic feedback are the most effective methods. Likewise, some other teachers stated that recast and elicitation together were the most effective types (10\%). It seems that half of the teachers believe that Recast is the most effective corrective feedback type, either together with other types of CF or alone. 30 percent of the participant teachers favored Recast alone over the other types. 20\% of teachers stated that metalinguistic 
feedback is the most useful one.There is more consensus on the least helpful type of corrective feedback. While $60 \%$ of participants stated that explicit corrections have the least impact, $10 \%$ reported the clarification request as the least instrumental corrective feedback method. Twenty percent cited explicit treatments and recasts as the least effective combination. Only one instructor rated clarification request as the least useful type and said, "It is like saying "Sorry, what you have just said was total nonsense so can you come again? I think learners will feel discouraged if they are made to repeat the same sentence with "better" equivalents." One other participant teacher stated that "Explicit correction and recasts are not very useful since they give the correct answer to the students without making them think about their mistake." Another instructor meant explicit correction as his/her unfavorable correction type saying "Don't give the answer immediately. Explain the source of the problems."Based on his/her statement, it can be concluded that explicit corrections and recasts are minimal; metalinguistic feedback is the most effective type of corrective feedback. Another teacher stated that instant correction is not helpful for students, not mentioning any OCF type of Lyster\&Ranta's (1997) taxonomy. Due to their instant nature, it can be inferred that (s)he may have implied explicit correction or recasts.To be able to get a deeper understanding of the teacher beliefs, their comments on the prepared scenarios were also taken into consideration. The findings related to these scenarios are given in Figure 2 below:

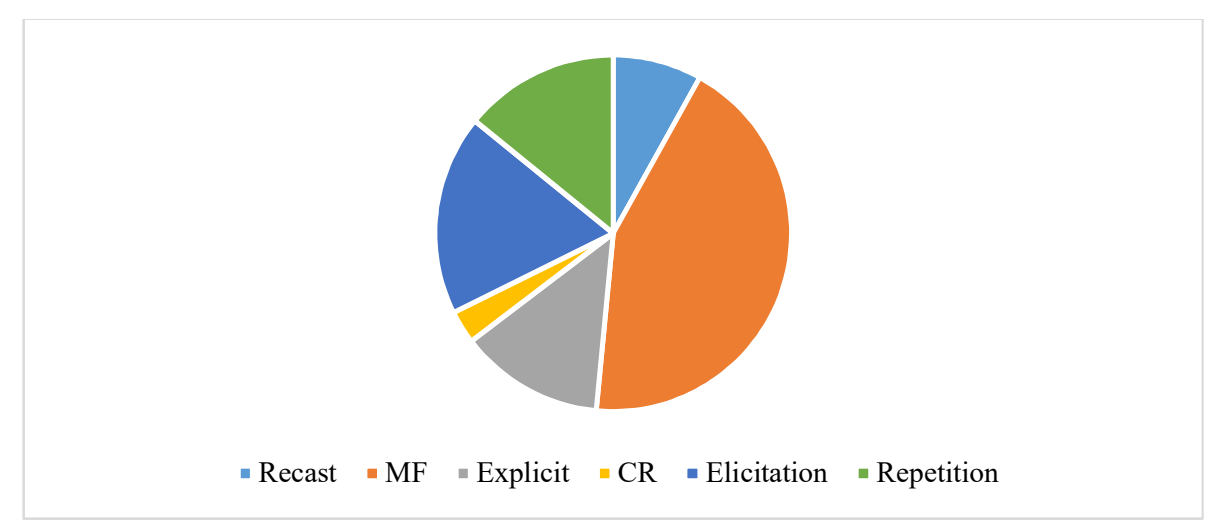

Figure 2: Distribution of Teachers' Provision of OCF Types for Scenario-based Errors

Regarding the distribution of corrective feedback preferences stated by the teachers to the three types of errors in the scenario-based handouts, as seen in Figure 2 the general preferences expressed by the teachers for correcting errors. They are metalinguistic feedback (43\%), elicitation (18\%), repetition (14\%), explicit correction (13\%), recasts (8\%) and clarification requests (3\%):As shown, metalinguistic feedback (43\%) was the most preferred type, among the others with a significant proportion.

Afterwards, what type of errors should be corrected was also taken into consideration. When teachers were asked what types of errors they would prefer to correct, such as grammar, pronunciation, or vocabulary, their answers varied. That is, 50 percent of the participants reported that they give equal importance to all of them to correct when required. Twenty percent of them prioritized vocabulary errors mentioning, "I give OCF more on vocabulary and then pronunciation because grammar errors are not an obstacle of being understood. For example, 'She go cinema yesterday'. Everyone understands what the speaker means in this example. In pronunciation, the obstacle may cause much more trouble." Out of ten instructors, only one said that she would she would prioritize grammar errors. We also investigated their beliefs related to the types of errors to be corrected through scenarios and the results are given in Table 4 below: 
1112 / RumeliDE Journal of Language and Literature Studies 2021.25 (December)

Unravelling the beliefs and practices of EFL teachers related to corrective feedback in Turkey / Z. Çoban; B. İnan Karagül (pp. 1103-1119)

Table 4: Distribution of Corrected and Ignored Error Types in Scenario-based Error Correction Handout

\begin{tabular}{lll}
\hline Types of Errors & Corrected (\%) & Ignored (\%) \\
\hline Grammar & 63 & 37 \\
Pronunciation & 93 & 7 \\
Vocabulary & 97 & 3 \\
\hline
\end{tabular}

However, the teachers' most preferred error type to correct was vocabulary errors (97\%) in scenariobased error correction sheet, followed by pronunciation (93\%) and grammar errors (63\%) (see Table 4).

Table 5: Distribution of Corrected and Ignored Error Types

\begin{tabular}{llllll}
\hline Types of Errors & $\begin{array}{l}\text { Errors } \\
\text { no }\end{array}$ & $\begin{array}{l}\text { Corrected } \\
\text { no }\end{array}$ & $\begin{array}{l}\text { Corrected } \\
\%\end{array}$ & $\begin{array}{l}\text { Ignored } \\
\text { no }\end{array}$ & $\begin{array}{l}\text { Ignored } \\
\%\end{array}$ \\
\hline Grammar & 110 & 56 & $51 \%$ & 54 & $49 \%$ \\
Pronunciation & 80 & 52 & $65 \%$ & 28 & $35 \%$ \\
Vocabulary & 35 & 29 & $83 \%$ & 6 & $17 \%$ \\
Total & 225 & 137 & $61 \%$ & 88 & $39 \%$ \\
\hline
\end{tabular}

As seen in Table 5, lexical errors were the type that students made the least during the class observations taking up $16 \%$. It seems that while they had the least ignorance rate among the three types, they came first in errors corrected with the highest percentage (83\%) of treatment. The results appear to indicate that the teachers' classroom practices tend to be in agreement with their performance in the scenariobased error correction phase. However, this is not the case with their stated beliefs. 70 percent of the teachers were likely to treat all the lexical errors, which, as mentioned above, were the least common type of error in six teacher classes and the second most common error type in two teacher classes. On the other hand, , grammar errors formed 49 percent of all the errors made in the class. Corrected and uncorrected errors were very close in grammatical ones (51 and $49 \%$, respectively). The reason why almost half of grammatical errors were not corrected may be that the observed lessons were all listening and speaking skill lessons, which means that the target of the lessons was not grammar. Pronunciation was the second most common type of error comprising 36 percent of the errors and also it was the second type of error corrected and ignored accordingly. All in all, the observed consistency exists between the participating teachers' scenario-based error correction and their actual practices rather than their beliefs.

\section{Discussion}

This study aimed to identify the oral corrective feedback beliefs and practices of EFL teachers and to unravel the (in)congruence between their beliefs and practices of OCF. Related to whether or not to supply corrective feedback, all participating instructors agreed that OCF has a positive impact on L2 teaching and learning, especially when provided in appropriately. In line with this, several teachers observed explained that continuous and explicit feedback has an adverse effect on learners' affective condition and motivation, citing its benefits as long as it does not lead discouragement or demotivation of students. It may also cause communication breakdown. This idea is consistent with Krashen (1982) and Truscott's (1999), who are against correcting students' spoken errors. Truscott (1999) suggested that correcting students' grammatical errors by means of oral corrective feedback distracts their attention from the communicative activity. Likewise, Roothooft (2014) suggested that correcting learners during speaking may hinder the flow of communication. In this context, more empirical studies 
are required to explore the effectiveness of correcting communicative tasks during and after the activity. The findings of this research also show consistency with a number of studies that are against overcorrection of students' mistakes (Edge, 1989; Jean \& Simard, 2011; Ur, 1996). For instance, in Jean and Simard (2011), the teachers were in agreement on correcting mistakes that only stop the flow of communication, so as not to reduce students' confidence. Concerning the benefits of OCF for language acquisition, their beliefs about OCF were also consistent with most of the research claiming that CF promotes students' interaction skills (Bruton 2010; Lyster et al., 1999; Nassaji 2009). The reasons why the teachers believed the negative effects of overcorrection and strongly sipported the appropriate provision of OCF types overlap with the results of some studies (Kaivanpanah et al., 2015).

Regarding whether or not to correct students' errors, all teachers agreed that students should be given feedback in the classroom for their incorrect utterances. In this context, this study is in line with Gurzynski-Weiss (2010) and Rahimi and Zhang (2015). The findings of Rahimi and Zhang's (2015) research showed that most experienced teachers and novice teachers agreed on correcting students' mistakes in communicative activities. As to the teachers in Gurzynski-Weiss's (2010) study, both native and non-native speaker teachers believed that students should be provided corrective feedback considering the linguistic target of the class.

Concerning OCF types, the majority of teachers in this study tended to be in agreement with the effectiveness of output-prompting types of feedback (mostly elicitation and metalinguistic feedback with elicitation together). This is consistent with previous research that found that prompts function better than recasts (Ammar \&Spada, 2006; Lyster, 2004). This study also shows consistency with Yoshida's (2010), which the researcher concluded that from a pedagogical point of view, elicitation strategies are more preferred since students are more engaged in the linguistic target (Ammar \&Spada, 2006; Lyster, 2004); Nassaji 2007; Yang \&Lyster, 2010). Egi (2007) also stated that students have tendency to notice explicit strategies better than the others. However, a small number of teachers believed that the most effective type of OCF is recasts. They were consistent with a few researchers in their beliefs (Doughty, 2001; Long, 2006) reporting the effectiveness of recasts, but inconsistent with some others (Lyster, 1998; Lyster\&Ranta, 1997; Panova\&Lyster, 2002). They claimed that recasts are not useful for language development because they do not produce uptake or repair.

With regard to the errors to be corrected, the teachers first reported their error type preference to correct or not to correct in general. They argued that teachers should correct the errors that create ambiguity and negatively affect linguistic purpose. However, they argued that teachers should not address mistakes that do not hinder fluency or the flow of communication. In this sense, while only a very small percentage of teachers prefer to correct errors related to the focus of the lesson, a higher approval rate (almost half of FSL teachers and slightly more than half of EFL teachers) was reported in the study by Jean and Simard (2011). Likewise, Burt (1975) suggested that teachers focus on the errors that affect the whole sentence structure and are believed to cause deterioration in communication. Consistent with the results of this recent study on students' affective states, Agudo (2014) found that more than half of the teachers surveyed preferred to address only a few errors so as not to deter students. Regarding the errors that disrupt the flow of communication, most of the teachers in the present study agreed to correct such errors. This finding contradicts Schulz (1996) with which only a small number of foreign language teachers agreed. On the other hand, this study is in good agreement with the study by Jean and Simard (2011) that more than half of FSL teachers and nearly two-thirds of ESL teachers prefer to correct errors that lead to communication disorders. This present study is also consistent with the one by Bell (2005). In both studies, only a small proportion (almost one-fifth) of teachers felt that most errors should be 
corrected, but most teachers felt that some types of errors should be left uncorrected. In Agudo (2014), just over a third of teachers surveyed favored correcting all grammatical errors, while the proportion of teachers in the current study favoring correcting all grammatical errors was very low (one tenth).

Relevant to the relationship between teachers' beliefs about whether to provide OCF or not and their OCF practices, participating teachers resisted providing OCF in order not to hinder communication during communicative activities. In this context, this study is compatible with many studies in terms of belief-practice agreement (Bastürkmen et al., 2004; Bohlke, 2014; Dilans, 2015; Roothooft, 2014). For example, similarly, in Bohlke's (2014) study, teachers stated that they objected to correcting students' incorrect utterances during communicative activities. However, they provided correction during speaking activities in their classroom practices. Likewise, Baştürkmen et al., (2004) stated that there is an inconsistency between the beliefs expressed by the teachers and their actual classroom practices. In their study, although all of them believed that students should not be corrected during speaking performance, they frequently provided it. They stated that the unplanned nature of the feedback led to this. In the interviews, the researchers concluded that the teachers responded to the interview questions based on their theoretical knowledge. But when faced with real classroom situations, the teachers unconsciously applied to their practical experience with language teaching. The current study is also in line with Roothooft's (2014) research, which investigated the relationship between teachers' beliefs about oral corrective feedback and their practices. Teachers' beliefs of OCF often did not coincide with their classroom practice. Roothooft (2014) commented that teachers were not always aware of the frequency and the types of feedback they used to correct their students' errors. The nature of OCF may explain why the amount of $\mathrm{OCF}$ in the classroom practices significantly exceeded the amount anticipated by the teachers. In the same way, Dilans' (2015) research showed that there was inconsistency between teachers' perceptions and practices towards OCF. The findings from classroom observations were different from the results of the survey results in that recasts took up an overwhelming percentage of $\mathrm{CF}$ episodes, followed by explicit correction and elicitation, at the same rate.

In this study, only a third of teachers stated recasts alone, and a very small minority reported recasts along with metalinguistic feedback as the most effective types of corrective feedback. However, recasts formed the largest proportion of feedback episodes. The results were in agreement with several previous studies (Baştürkmen et al., 2004; Dong, 2012; Lyster and Ranta, 1997; Yoshida, 2008). For instance, in Lyster and Ranta's (1997) study, all teachers they observed used recasts more than any other type of CF. Recasts made up more than half of the feedback attempts given in their four classes. Although teachers believed the effectiveness of elicitation, which allows students to self-correct, they consistently used recasts in their practices. In a similar way, Yoshida (2008) found that although teachers stated that prompts were more beneficial in terms of giving learners the opportunity to correct themselves, they provided recasts in the classroom because they create an environment conducive to learning and because they scaffold learners. In Basturkmen et al., (2004) and Dong (2012), the instructors reported their preference of prompts to treat students' incorrect utterances, but they mostly used recasts in their lessons. In their study and in this study, teachers suggested that maintaining a positive emotional classroom atmosphere was their priority since anxiety prevents students from benefiting from $\mathrm{CF}$. Similarly, teacher candidates in Vasquez and Harvey's (2010) study were also interested in affective measures for correcting their students. The findings of the current research are also consistent with the results of Sepehrinia and Mehdizadeh's (2016) study, which the teachers avoided using elicitation in their observed classrooms despite expressing strong belief that elicitation can contribute to effective learning. One possible explanation for this is that forcing students to produce in front of the class can lead to stress and frustration in learners. Likewise, the findings of this study are consistent with the 
findings of Yoshida's (2010) research that teachers participating in the research do not want to embarrass their students in front of the class, especially when their students' proficiency levels do not allow them to correct their own mistakes. In line with this view, the present study is in agreement with Bell's (2005) research findings that teachers prefer to correct students' mistakes through recasts. This may be attributed to the influence of language teaching literature and teacher training courses, which often highlight the potential negative effects of explicit types of CF (Harmer, 2007).

When it comes to the participating teachers' scenario-based error correction practices, it was observed that they were in line with their practices in their classrooms. In those scenerios, the teachers preferred to correct more than half of the errors. The reason why the percentage of scenario-based implementation was higher than in real classrooms might stem from the fact that there was no concern, such as interruption of the flow of communication in the classroom environment.To summarize, most teachers were consistent in their beliefs and practices although there were some discrepancies between expressed beliefs about whether OCF was effective or not and teachers' classroom practices. Regarding this inconsistency, it can be concluded that a few teachers expressed their reservations as an affective reaction to the interruption of the communication flow and the correction of the students by their teachers. In line with this, the unwillingness of these teachers to offend and deter their students may have caused these inconsistencies. The majority of the participating teachers repeated their views regarding OCF in the interviews and reflected them in their classroom practices. In this vein, it has been observed that there is consistency between their beliefs and classroom practices.

Still, there were obvious examples of inconsistencies with several previous studies (Dong, 2012; Kamiya, 2016; Kartchava, 2006). Contrary to this research, which mainly found discrepancies between the beliefs and practices expressed by the teachers, in Kamiya's (2016) research, teachers did not value explicit correction and therefore never used it. In Kartchava (2006), teachers opted for recasts and used it in their classrooms to correct students' mistakes. In Dong (2012), teachers preferred implicit feedback and mostly provided refactoring as a type of implicit corrective feedback. Similar to the studies mentioned above in this paragraph, which yielded consistent results between teachers' beliefs and practices, the current study also produced some consistencies in the case of explicit correction.

\section{Conclusion}

The findings of the present study suggest that all the participant teachers acknowledge the necessity of OCF in the language teaching process but they also emphasize using it judiciously because it is believed that if it is provided continuously and explicitly, it might lead to some negative emotional response on students' side. It was also observed that the participant teachers corrected more errors during scenariobased interviews than their actual classroom practice since all of them were quite cautious about not to stop the flow of the classroom communication.

This study is not without limitations. To be able to get a clearer picture of the important relationship between teachers' beliefs and practices related to oral corrective feedback, some other data collection methods could be employed; namely, stimulated recall, survey, etc. Another possibility for future research could be including more participants, specifically from different school levels, which will definitely yield a more comprehensive picture of the issue under investigation. Such kind of analysis would be a lot more helpful if the findings could be incorporated more to teacher training. This could be done with the help of including these OCF strategies in second language teacher education (SLTE) 
programs (Agudo, 2014; Özmen \& Aydın, 2015) and teacher trainees could build up their own pedagogy accordingly.

\section{References}

Agudo, J. (2014). Beliefs in learning to teach: EFL student teachers' beliefs about corrective feedback. Utrecht Studies in Language and Communication, 27, 209-362.

Allwright, D., \& Bailey, K. M. (1991). Focus on the language learner. Cambridge: Cambridge University Press.

Ammar, A., \&Spada, N. (2006). One size fits all? Recasts, prompts and L2 learning. Studies in Second Language Acquisition, 28, 543-574.

Bai, B., Yuan, Y. (2018). EFL teachers' beliefs and practices about pronunciation teaching. ELT Journal, 73(2), 134-143.

Basturkmen, H., Loewen, S., \& Ellis, R. (2004). Teachers' stated beliefs about incidental focus on form and their classroom practices. Applied Linguistics, 25, 243-272.

Bell, T. (2005). Behaviors and attitudes of effective foreign language teachers: Results of a questionnaire study. Foreign Language Annals, 38(2), 259-270.

Bohlke, D. (2014). Fluency-oriented second language teaching. In M. Celce-Murcia, D. Brinton \& M. Snow (Eds.), Teaching English as a Second or Foreign Language, fourth edition (pp. 121-135). Boston, MA.: Heinle Cengage.

Borg, S. (2006). Teacher cognition and language education: Research and practice. London: Continuum.

Borg, S. (2011). The impact of in-service teacher education on language teachers' beliefs. System, 39, $370-380$.

Bruton, A. (2010). Another reply to Truscott on error correction: improved situated designs over statistics. System,38(3), 491-8.

Burt, M. (1975). Error analysis in the adult EFL classroom. TESOL Quarterly, 9, 53-63.

Dilans, G. (2015). Corrective feedback in L2 Latvian classrooms: Teacher perceptions versus the observed actualities of practice. Language Teaching Research, 20(4), 479-497.

Dong, Z. (2012). Beliefs and practices: A case study on oral corrective feedback in the teaching Chinese as a foreign language (TCFL) classroom. MA thesis, Arizona State University, US.

Edge, J. (1989). Mistakes and correction. London: Longman.

Egi, T. (2007). Recasts, learners' interpretations, and L2 development. In A. Mackey (Ed.), Conversational interaction in second language acquisition (pp. 249-360). New York: Oxford University Press.

Doughty, C. (2001). Cognitive underpinnings of focus on form. In P. Robinson (Ed.), Cognition and second language instruction (pp. 206-57). Cambridge: Cambridge University Press.

Ellis, R. (2012). Language teaching research and language pedagogy. London: Wiley-Blackwell.

Gaitas, S., \& Martins, M. A. (2014). Relationships between primary teachers' beliefs and their practices in relation to writing instruction. Research Papers in Education, 3O(4), 492-505.

Gurzynski-Weiss, L. K. (2010). Factors influencing oral corrective feedback provision in the Spanish foreign language classroom: Investigating instructor native/nonnative speaker status, second language acquisition education, \& teaching experience. $\mathrm{PhD}$ dissertation, Georgetown University, US.

Harmer, J. (2007). The practice of English language teaching. Harlow, UK: Pearson.

Hendrickson, J. (1978). Error correction in foreign language teaching: Recent theory, research, and practice. Modern Language Journal, 62, 387-398. 
Hsiang, T. P., Graham, S., \& Yang, Y. (2020). Teachers' practices and beliefs about teaching writing: A comprehensive survey of grades 1 to 3 teachers. Reading and Writing, 33, 2511-2548.

Jean, G., \& Simard, D. (2011). Grammar teaching and learning in L2: Necessary, but boring? Foreign Language Annals, 44(3), 467-494.

Jensen, M.T. (2001). Corrective feedback to spoken errors in adult ESL classrooms. Unpublished doctoral dissertation, Monash University, Clayton, VIC, Australia.

Kaivanpanah, S., Alavi, S. M., \&Sepehrinia, S. (2015). Preferences for interactional feedback: differences between learners and teachers. The Language Learning Journal, 43(1), 1-20.

Kamiya, N. (2016). The relationship between stated beliefs and classroom practices of oral corrective feedback. Innovation in Language Learning and Teaching, 1O(3), 206-219.

Kartchava, E. (2006). Corrective feedback: Novice ESL teachers' beliefs and practices. MA thesis, Concordia University, Canada. 24.

Krashen, S. D. (1982). Principles and practice in second language acquisition. Oxford: Pergamon Press.

Kurbaniyova, M., \&Feryok, A. (2015). Language teacher cognition in applied linguistics research: Revisiting the territory, redrawing the boundaries, reclaiming the relevance. The Modern Language Journal, 99(3), 435-449.

Kuzborska, I. (2011). Links between teachers' beliefs and practices and research on reading. Reading in a Foreign Language, 23(1), 102-128.

Long, M. (2006). Recasts in SLA: The story so far. In M. Long (Ed), Problems in SLA (pp.75-116). Mahwah: Lawrence Erlbaum.

Lyster, R. (1998). Recasts, repetition, and ambiguity in L2 classroom discourse. Studies in Second Language Acquisition, 20, $51-81$.

Lyster, R. (2004). Differential effects of prompts and recasts in form-focused instruction. Studies in Second Language Acquisition, 26, 399-432.

Lyster, R., \&Ranta, L. (1997). Corrective feedback and learner uptake: Negotiation of form in communicative classrooms. Studies in Second Language Acquisition, 19, 37-66.

Lyster, R., Lightbown, P., \&Spada, N. (1999). A response to Truscott's 'What's wrong with oral grammar correction.' Canadian Modern Language Review, 55, 457-467.

Mardali, J., Siyyari, M., \& Lu, X. (2019). English teachers' beliefs and practices in teaching vocabulary: The case of teaching experience. Cogent Education, 6(1), 1-33.

Nassaji, H. (2009). Effects of recasts and elicitations in dyadic interaction and the role of feedback explicitness. Language Learning, 59, 411-452.

Nassaji, H., \&Kartchava, E. (2017). The role of corrective feedback:Theoretical and pedagogical perspectives. In H. Nassaji\& E. Kartchava (Eds.), Corrective Feedback in Second Language Teaching and Learning,(ix-xv), Routledge.

Neuendorf, K.A (2002). The content analysis guidebook. Thousand Oaks, CA: Sage.

Ölmezer-Öztürk, E. (2019). Beliefs and practices of Turkish EFL teachers regarding oral corrective feedback: A small-scale classroom research study. The Language Learning Journal, 47(2), 219228.

Özmen, K. S., \& Aydın, H. Ü. (2015). Examining Student Teachers' Beliefs about Oral Corrective Feedback: Insights from a Teacher Education Program in Turkey. Australian Journal of Teacher Education, 4O(12), 141-164.

Panova, I., \&Lyster, R.(2002). Patterns of corrective feedback and uptake in an adult ESL classroom. TESOL Quarterly, 36, 573 - 595.

Patton, M. W. (2002). Qualitative evaluation and research methods (3rd ed.). Thousand Oaks, CA: Sage. 
Rahimi, M., \& Zhang, L. (2015). Exploring non-native English-speaking teachers' cognitions about corrective feedback in teaching English oral communication. System, 55, 111-122.

Ranta, L., Lyster, R. (2007). A cognitive approach to improving immersion students' oral language abilities: The awareness-practice-feedback sequence. In DeKeyser, R. (Ed.), Practice in a Second Language: Perspectives from Applied Linguistics and Cognitive Psychology (pp. 141-160). Cambridge: Cambridge University Press.

Richards, J. (1998). Beyond Training. Cambridge. Cambridge University Press.

Roothooft, H. (2014). The relationship between adult EFL teachers' oral feedback practices and their beliefs. System, 46, 65-79.

Schulz, R. A. (1996). Focus on form in the foreign language classroom: Students' and teachers' views on error correction and the role of grammar. Foreign Language Annals, 29, 343-364.

Sepehrinia, S., \&Mehdizadeh, M. (2016). Oral corrective feedback: teachers' concerns and researchers' orientation. The Language Learning Journal, 46(4), 483-500.

Spada, N., \&Fröhlich, M. (1995). COLT. Communicative Orientation of Language Teaching observation scheme: Coding conventions and applications. Sydney, Australia: National Centre for English Language Teaching and Research.

Spada, N., \&Lightbown, P. M. (2009). Interaction research in second/foreign language classrooms. In A. Mackey\& C. Polio (Eds.), Multiple Perspectives on Interaction (pp. 157 - 175). London: Routledge.

Truscott, J. (1999). 'What's wrong with oral grammar correction.' Canadian Modern Language Review, 55: 437-56.

Uysal, H. H., \&Bardakçı, M. (2014). Teacher beliefs and practices of grammar teaching: Focusing on meaning, form or forms? South African Journal of Education, 34(1), 1-16.

Vasquez, C., \& Harvey, J. (2010). Raising teachers' awareness about corrective feedback through research replication. Language Teaching Research, 14(4), 421-443.

Yang, Y., \&Lyster, R. (2010). Effects of form-focused practice and feedback on Chinese EFL learners' acquisition of regular and irregular past tense forms. Studies in Second Language Acquisition, 32(2), 235-263.

Yoshida, R. (2010). How do teachers and learners perceive corrective feedback in the Japanese language classroom? The Modern Language Journal, 94(2), 293-314.

\section{Appendix}

Please read the following examples and decide whether you would correct the following errors in each situation. If you would, which OCF (Oral Corrective Feedback) strategies would you employ?

\begin{tabular}{|c|c|c|}
\hline Erroneous sentences & $\begin{array}{l}\text { Your attitude } \\
\text { Would you correct this error? }\end{array}$ & $\begin{array}{l}\text { If yes, } \\
\text { Which CF strategy would you } \\
\text { use? }\end{array}$ \\
\hline $\begin{array}{l}\text { 1. T: What was your responsibility } \\
\text { in your internship? } \\
\text { S: I was cutting tickets. }\end{array}$ & $\begin{array}{l}\text { a) Yes } \\
\text { b) No }\end{array}$ & $\begin{array}{l}\text { (a) 'checking-in' } \\
\text { (b) 'not cutting tickets, say } \\
\text { checking-in' } \\
\text { (c) 'You work as a ticket agent and } \\
\text { help passengers at an airport, what } \\
\text { verb do we use for it?' } \\
\text { (d) 'CUTTING TICKETS (with a } \\
\text { rising intonation)' }\end{array}$ \\
\hline
\end{tabular}


RumeliDE Dil ve Edebiyat Araştırmaları Dergisi 2021.25 (Aralık)/ 1119

Türkiye'deki İngilizce öğretmenlerinin düzeltici geri bildirimle ilgili inanç ve uygulamalarının belirlenmesi / Z. Çoban; B. İnan Karagül (1103-1119. s.)

\begin{tabular}{|l|l|l|}
\hline & $\begin{array}{l}\text { (e) 'Sorry?' or 'Can you repeat that } \\
\text { again?' } \\
\text { (f) ‘I was ....?' (you omit the } \\
\text { erroneous part of the sentence and } \\
\text { repeat the sentence with a rising } \\
\text { intonation) }\end{array}$ \\
\hline
\end{tabular}

